\title{
Corporate sponsorship and health halo for ultra-processed products
}

\section{Qualitative study on the 21st International Congress of Nutrition}

\section{Authors:}

Laura Raquel Piaggio, Social Anthropologist, Nutritional Program - Ministry of Health of the City of Buenos Aires, Argentina

https://orcid.org/0000-0002-2951-6305

piaggiolau@gmail.com

Andrea Mónica Solans, Master's Degree in Social Anthropology, Health and Anthropology Program - Faculty of Philosophy and Literature - University of Buenos Aires, Argentina

amsolans@gmail.com

Funding: No specific funding was received for this study. LP was supported by her permanent job at the Ministry of Health of Buenos Aires City Government, institution that awarded a scholarship to attend the Congress. AS was supported by her work as a teacher of Anthropology and her participation in the Anthropology and Health Program of the Faculty of Philosophy and Literature, Buenos Aires National University. This Program faced the payment of her registration to the Congress.

Competing interests: Both authors have completed the ICMJE uniform disclosure form at www.icmje.org/coi_disclosure.pdf and have nothing to disclose, since there has been no support from any organisation for the submitted work and no financial relationships with any organisations that might have an interest in the submitted work in the previous three years.

Ethical approval: This study followed an observation and documentary approach. Besides, there were no patients involved. Therefore, it is framed within the exceptions regarding the requirement of a revision by an Ethics Committee for the Research, as well as the administration of an informed consent, as per Resolution 1480/2011 issued by the Ministry of Health of the Argentine Republic (http://www.anmat.gov.ar/webanmat/legislacion/medicamentos/Resolucion_14802011.pdf).

Acknowledgment: The authors thank the anonymous reviewers and the editor for their careful reading of our manuscript and their many valuable and clarifying comments and suggestions. 


\section{ABSTRACT}

\section{Objective}

To describe the characteristics of corporate sponsorship during the 21st International Congress of Nutrition provided by food companies, and to analyse the measures proposed by the organizers to deal with prospective conflicts of interest.

\section{Design}

Qualitative study based on participant observation and document analysis.

\section{Setting}

21st International Congress of Nutrition, Buenos Aires, October 2017.

\section{Analysis}

The nutritional profile of the products advertised in the area of commercial exhibition was analysed according to the PAHO Nutrient Profile Model. The document analysis was based on the grounded theory to propose conceptual categories that organize the narratives on the aforementioned products.

\section{Results}

Large food corporations sponsoring the Congress advertised a selection of their products to health professionals and other participants attending the event. 92\% of the exhibited food products were ultra-processed. 85\% were high in added sugars, sodium, and/or saturated fats. Despite this unsuitable nutritional profile, narratives to endow ultraprocessed products with a health halo were developed through three thematic axes: fortification with micro-nutrients, reformulation of products and symbolic reconversion of snacks by creating a positive assessment and removing negative connotations.

The measures adopted by the organization to deal with prospective conflicts of interests included space-time segmentation of activities and the requirement for the lecturers to submit a statement declaring their funding sources limited to each presentation. Spacetime restrictions proved insufficient, and the declaration of funding sources was not a requirement for institutions organizing the symposia.

\section{Conclusions}

The influence of corporate sponsorship by food companies in the topics of scientific debate and dietary recommendations leads to questioning the efficacy of the measures adopted by the organizers to deal with the conflicts of interests. Said measures have been characterized as an institutionalized opacity policy.

It is necessary to define stricter standards to prevent sponsorship from companies that commercialize unhealthy products and/or that advertise products in an unsuitable way.

\section{KEYWORDS:}

Financing of Congresses and Scientific Meetings; Food Industry; Food Publicity; Conflict of Interest 


\section{INTRODUCTION}

International congresses of nutrition have been held every four years since 1952, co-organized by the International Union of Nutritional Sciences (IUNS) and the Society of Nutrition of the country chosen as venue (Underwood, 2007). The purpose of organizing scientific international meetings is to disseminate advances in research, to facilitate the gathering and exchange among scientists from different regions, and to provide a training space for young professionals (Ioannidis, 2012).

The 21st IUNS Congress was held in Buenos Aires, Argentina, in 2017, in a five-star hotel located in the financial district. There were 3,038 participants. The scientific programme comprised 24 satellite symposia, 6 plenary lectures, 40 special lectures, 108 parallel symposia, and 28 sponsored symposia. It was sponsored by large companies producing foods, additives, diet supplements (International Union of Nutritional Sciences, n.d.).

There is an increasing concern within the scientific community regarding the impact of corporate sponsorship of congresses and seminars. It has been argued that such sponsorship may condition the contents of scientific discussion, facilitating the dissemination of industry-funded research, thus influencing the vision of health-care professionals towards companies, brands, and products exhibited in commercial stands (Bodini et al., 2009; Canella et al., 2015; Gomes, 2013; Ioannidis, 2012; Nestle, 2018). Similarly, it has been claimed that said influence may take the form of dietary recommendations and the public policies to implement them (Freedhoff \& Hébert, 2011; Gomes, 2015). Financial support from companies producing foods and drinks for organizing scientific meetings involves inescapable conflicts of interest.

A conflict of interest arises when a professional criterion regarding a primary interest tends to be unduly biased by a secondary interest (Richter, 2005). At an institutional level, such conflict occurs when a financial interest puts the mission and the entity's primary interest at risk (Institute of Medicine, 2009). A robust management of conflicts of interest helps preserve the integrity and credibility of institutions and protect public interests (WHO, n.d.).

In this article we will discuss the policy put forward by the IUNS to deal with the conflicts of interest presented by corporate sponsorship of their congresses. First we will describe the commercial exhibition area of the 21st International Congress of Nutrition held in Buenos Aires, and we will analyse the nutritional profile of the products exhibited at the stands. Next, we will identify the food companies' participation in the organization of symposia and the presence in other activities of the programme by lecturers participating in said sponsored symposia. Finally, we will analyse the narratives included in the flyers to present as healthy the products mentioned at the stands, and we will indicate certain connections with the presentations in sponsored events and other scientific activities.

\section{MATERIALS AND METHODS}

This was a qualitative study, where various research strategies included participant observation (Guber, 2001) and document analysis (Peña Vera \& Pirela Morillo, 2007). Participant observation was conducted in different spaces (Floor -1 , ground floor, $1^{\text {st }}, 2^{\text {nd }}$ and $24^{\text {th }}$ floors of Convention Centre) where the commercial and scientific activities took place.

We collected all the flyers offered at the commercial stands during the six days of the Congress (October $15^{\text {th }}$ to $20^{\text {th }}$, 2017) and we kept a photographic record of each stand and of the common spaces where lunch was offered to the attendees. The authors attended sponsored symposia, conferences, and parallel symposia. The information collected personally was supplemented by the Programme and the Book of Abstracts (Carrera et al., 2017) available at the Congress official web page.

A spreadsheet was prepared to enter all the data related to the identification of the products exhibited in the panels and/or flyers of the companies producing foods and drinks. Other products like additives, dietary supplements, and drugs were excluded because the focus was on the analysis of the nutritional profile of foods and beverages. The variables were itemized as follows: company, 
commercial name, type of product. Both authors coded all the products separately to then make a comparison to ensure data reliability, finding a $90 \%$ of coincidence and correcting the other $10 \%$.

The products under review were identified in the flyers or panels based on the name or through their image. When only the logo or name of the brand was included in the flyers, the photographs of the stands were checked to seek the specific product of the brand exhibited. In the case of a company that did not have a commercial stand and whose flyers (delivered in the Congress bag) stated the brand of the product (premixes for desserts) without specifying the flavour, information about the two flavours of the product was collected from the company's website, randomly selected.

The nutritional information was collected from the flyers, whenever it was available. It was necessary to supplement this information with searches on the official sites of the companies or on external web sites (where said information was not provided on the web sites of the products either). The NOVA classification system (Monteiro et al., 2019) was used to identify the food processing level of the products (minimally processed, processed culinary ingredient, processed, and ultra-processed), and we analysed critical nutrients, such as added sugars, sodium, saturated fat, according to the PAHO Nutrient Profile Model (PAHO, 2016).

Furthermore, we carried out a systematization of the organizing entities, the chairs and speakers in the different activities included in the Congress programme. It was necessary to resort to sources of information external to the Congress publications to find out the participation of food and beverages companies funding the organizing entities.

In addition, an analysis was performed of the contents obtained from the flyers and abstracts submitted, based on grounded theory methodology (Charmaz, 2006), aimed at identifying semantic elements used in the flyers' narratives (Harris, 2019) to describe the type of products exhibited as well as dietary recommendations. This was done through coding the texts to organize the information and build the analytical axes that helped characterize the narratives presented in the results.

\section{RESULTS}

\section{Commercial area}

The Congress included a commercial exhibition area with 23 stands, maintained throughout the six days of the event. Most were set up by large companies producing foods, additives, diet supplements, and drugs, and all of them were sponsors of the Congress.

After completing the required Congress registration, all of the participants crossed a hall arranged for commercial exhibition of the sponsoring companies in order to arrive at a desk (as shown in Figure 1) where the staff handed out a bag containing the map of the premises, a summarized programme of the whole event, a notepad, a ballpoint pen, and two flyers of Unilever, a company that did not have any commercial stand. On the provided bags, the name of one of the sponsors that had a stand was printed, a company producing dietary supplements (Herbalife).

This special arrangement was presented by the organizing committee as a way to differentiate the commercial aspect from the scientific one during the Congress experience. This was explained on a poster next to the entrance: "Following the directives of the ethics committee, this space has been designated for commercial activity exclusively".

The commercial exhibition area had 23 stands (Table 1): 9 for companies producing foods, 6 for companies producing additives and dietary supplements, 2 for pharmaceutical companies, 3 for companies producing measuring instruments, and 3 for other types of entities (Association and Congress of Food Technology, the Neuro-gastroenterology Society). The stands were of different sizes, the largest being those of Nestlé, General Mills, Mondelez and Danone, as shown in Figure 1. 
Figure 1. Commercial area map - IUNS 21 ${ }^{\text {st }}$ ICN Buenos Aires 2017

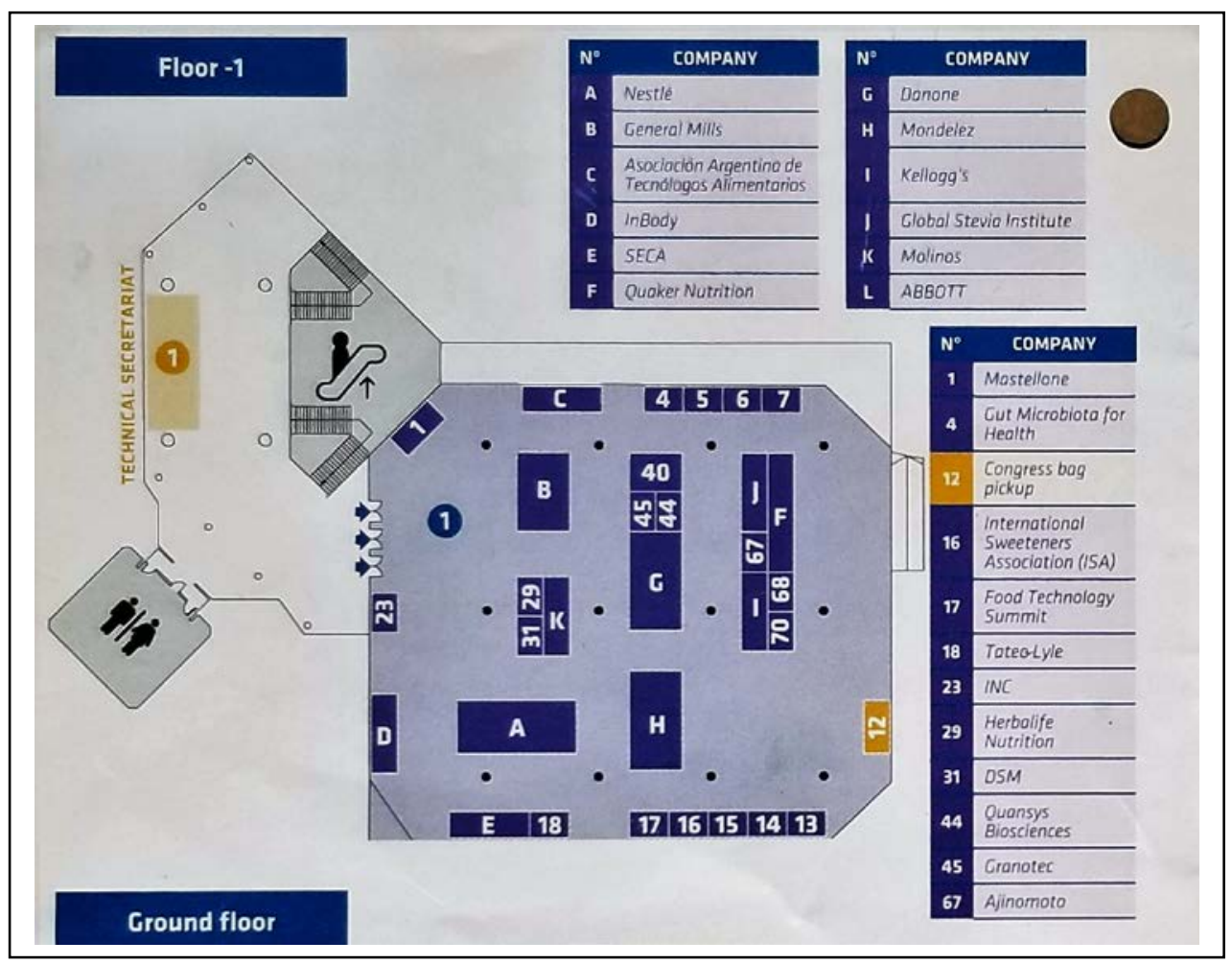

These were mostly transnational food corporations, known as "Big Food", since they control a significant if not oligopolistic portion of the food market worldwide. Few companies control more than a third of all the sales worldwide, expanding in countries of low and medium income (Stuckler \& Nestle, 2012). Out of the ten large companies identified in an infography prepared through OXFAM in 2013 (Hoffman, 2013), seven were present at the International Nutrition Congress held in Buenos Aires (Nestlé, PepsiCo, Kellogg's, General Mills, Danone, Mondelez, Unilever) (Figure 2).

Coca Cola did not have any stand and did not sponsor activities, as they had done at the previous International Nutrition Congress held in Granada (Spain) (Gomes, 2013); however, the company was the supplier for the drinks offered during lunch (sugared and artificially sweetened beverages) provided by the Congress organizers (Figure 3).

At the stands, notices were displayed with images and messages referring to the company, its brands and products, and flyers and/or booklets were handed out (Table 2). Furthermore, the companies producing foods offered free samples. The result was that during the intervals of the scientific programme, the commercial area was packed with people going over the stands and consuming free samples (yoghurts, flavoured milks, bottled water, coffee, cereals, cereal bars, crackers, etc.) (Figure 4).

\section{Nutritional composition of the foods and drinks offered at commercial} stands

The total number of exhibited/advertised products was 112 (Table 3). According to the NOVA classification system (Monteiro et al., 2019), which considers the industrial processing purpose and degree, it was observed that $92 \%$ were ultra-processed products. 
Table 1. Arrangement of the commercial exhibition area - IUNS 21 ${ }^{\text {st }}$ ICN Buenos Aires 2017

\begin{tabular}{ll}
\hline $\begin{array}{l}\text { Type of entity with } \\
\text { commercial stand }\end{array}$ & Name \\
\hline A) Nestlé \\
B) General Mills \\
\begin{tabular}{ll} 
Companies & F) Pepsico - Quaker Nutrition \\
producing & G) Danone \\
foods, & H) Mondelez \\
and corporate & I) Kellogg's \\
associations & K) Molinos \\
& 1) Mastellone \\
\hline Companies & 23) International Nuts Council \\
producing & 16) International sweeteners association \\
additives, & 18) Tate \& Lyle \\
dietary & 45) Granotec \\
supplements, and & 67) Ajinomoto \\
corporate & 29) Herbalife nutrition \\
associations & L) Abbott $\left.{ }^{*}\right)$ \\
\hline Pharmaceutical \\
companies
\end{tabular} 31) DSM \\
\hline Measuring & D) InBody \\
instruments & E) SECA \\
\hline Others & C) Quansys biosciences \\
\hline & 17) Food Technology Summit \\
\hline
\end{tabular}

${ }^{(*)}$ Note: Abbott is classified as a pharmaceutical company, despite its large portfolio that includes formula brands, because at the Congress it exhibited only enteral and parenteral nutrition products.

Figure 2. Top ten food and beverages corporations and their brands

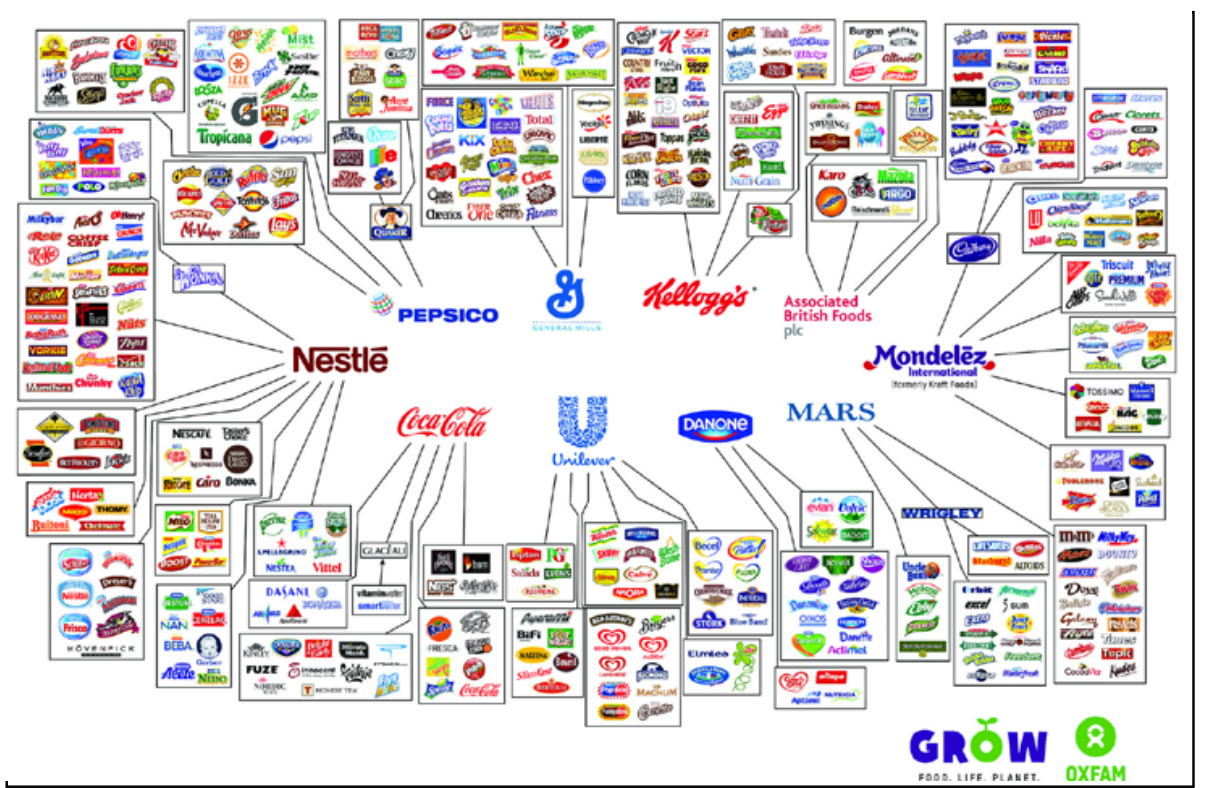

Oxfamamerica.org (For a larger image, visit https://tinyurl.com/oxfaminfography) 
Figure 3. Congress lunch- IUNS $21^{\text {st }}$ ICN Buenos Aires 2017

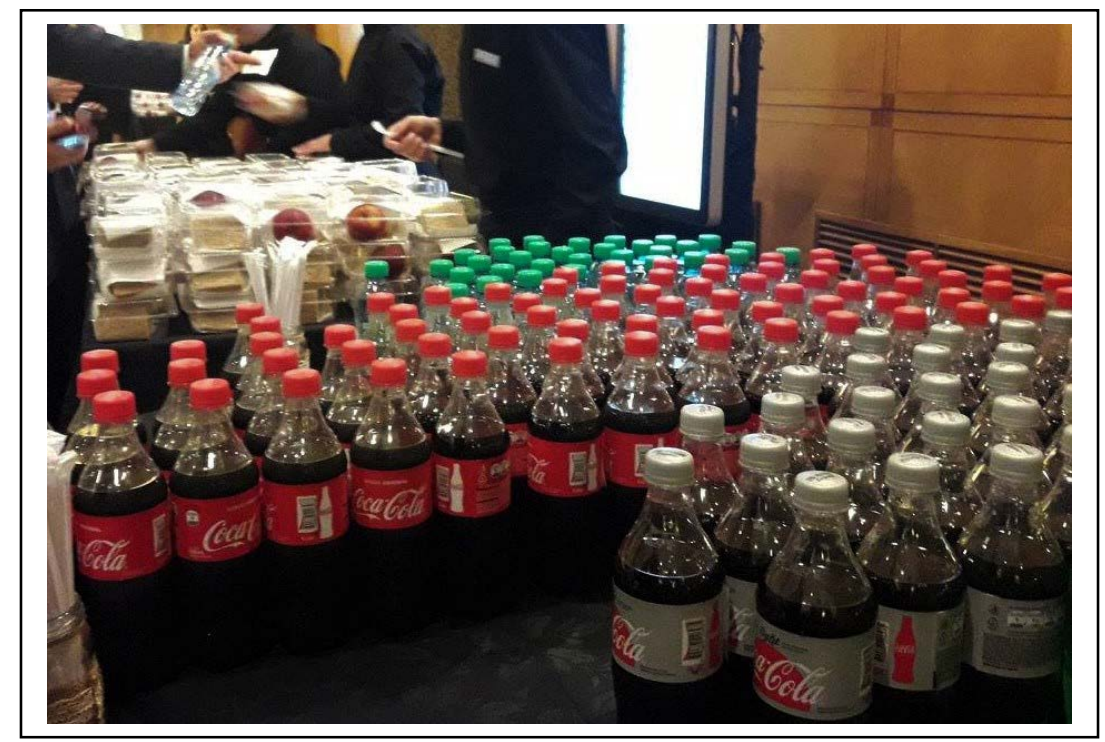

Photo: the authors

Figure 4. Free food and beverages in the commercial exhibition area - IUNS $21^{\text {st }}$ ICN Buenos Aires 2017

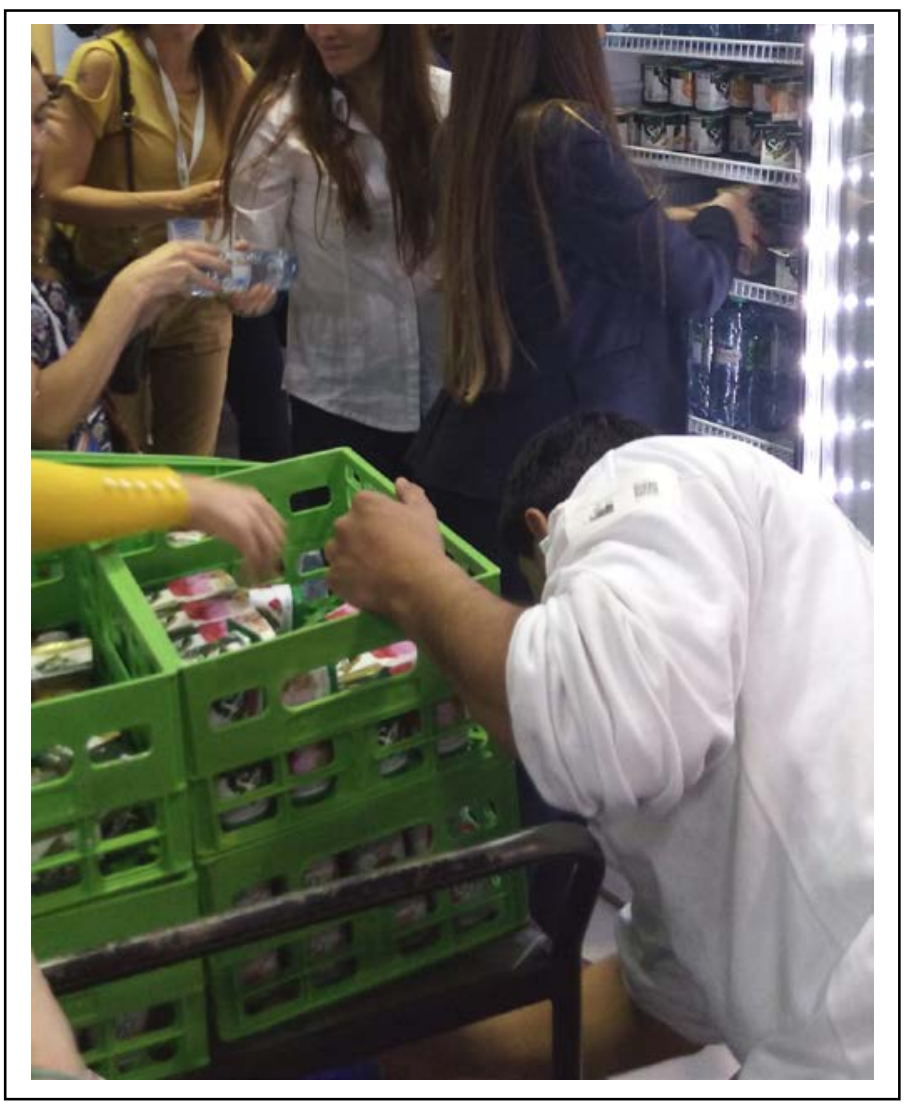

Photo: the authors 
Table 2. Food and beverages companies and their brands advertised at the commercial exhibition area - IUNS $21^{\text {st }}$ ICN Buenos Aires 2017

\begin{tabular}{lll}
\multirow{2}{*}{ Company } & \multicolumn{2}{l}{ Brands } \\
\cline { 2 - 3 } Nestlé & $\mathrm{n}$ & Names \\
\hline Mondelez & $\begin{array}{l}\text { Cerelac, Nestum, Mucilon, Gerber, Pure life, Snow flakes, Milo, Koko crunch, } \\
\text { Cheerios low sugar, Chocapic, Health Wise, Fit proteinness, Shreded wheat, } \\
\text { O\&G, Cheerios oats }\end{array}$ \\
\hline Danone & $\begin{array}{l}\text { Belvita, Saiwa, Fontaneda, Proalimentar, Opavia, Gyori, Liga, Triscuit, Good } \\
\text { Thins, Lu Belvita, Duo Fourre, Bio, Club social, Honey maid, Cerealitas }\end{array}$ \\
\hline General Mills & 12 & $\begin{array}{l}\text { Danonino, Danonki, Danino, Mellin Desert, Activia Prune, Bonafont, Milnutri, } \\
\text { Ser, Yogurisimo, Mizone, Mascot, Lactamil }\end{array}$ \\
\hline Unilever & $\begin{array}{l}\text { Haagen-Dasz, Oldelpaso, Nature valley, Yoplait greek, Fiber One, Cascadian } \\
\text { Farm, Larabar, La Salteña, Progresso, Gold Medal, Pillsbury }\end{array}$ \\
\hline Pepsico & 6 & $\begin{array}{l}\text { Knorr, Hellmann's, Maizena Cremogema, Maizena Crecinutre, Primavera, } \\
\text { Bonella }\end{array}$ \\
\hline Kellogg's & 5 & Quaker, Old fashioned, Super grains, Chewy, Simple granola Oats \\
\hline Molinos & 4 & Zucaritas, Corn flakes, Froot loops, Choco Krispys \\
\hline Mastellone & 4 & Chococrunch, Choconuss, Chocobar, Granja del Sol \\
\hline
\end{tabular}

We analysed the nutritional composition of ultra-processed products according to the parameters fixed by the PAHO Nutrient Profile Model (PAHO, 2016), which, in turn, is based on the limits of daily intake admitted for nutrients of concern (free sugars, sodium, saturated fats) established by the WHO. This model was developed to be applied exclusively to groups 3 and 4 of the NOVA classification (processed and ultra-processed) with the aim of guiding advertising regulation measures and front-of-package labelling, so it is not applicable to groups 1 and 2 (minimally processed foods and culinary ingredients).

In $77 \%$ of the cases it was necessary to carry out an ad hoc search of the nutritional information related to the products, because it was not included in the flyers handed out or in the notices displayed at the stands, nor were the back of package labels visible, since exhibits could not be manipulated.

Out of the 103 ultra-processed products, $60 \%$ exceeded thresholds for added sugars, $40 \%$ for sodium, and $27 \%$ for saturated fats. These percentages surpass $100 \%$, since a third of the products had more than one critical nutrient in excess (Table 4). The advertised products did not contain trans-fats of industrial origin, since in Argentina their use is officially regulated (ANMAT, 2014).

Of the 112 products displayed, only 15\% had an adequate nutritional profile, 8\% were minimally processed while $7 \%$ were ultra-processed without critical nutrients in excess: functional milks and few cereals for breakfast and cookies (Table 3). The remainder (85\%) contributed one or more nutrients of concern in excess (Figure 5).

\section{Scientific program, sponsored activities and statement declaring conflicts of interest}

The scientific programme comprised 24 satellite symposia, 6 plenary lectures, 40 special lectures, 108 parallel symposia, and 28 sponsored symposia. The abstracts of the presentations were published some days before the start date of the Congress in a special issue of the journal Annals of Nutrition and Metabolism (Carrera et al., 2017), even though it did not include the complete material (some presentations in symposia and even whole symposia), which were shown in the programme published on the web site. 
Table 3. Advertised products in the commercial exhibition area - IUNS $21^{\text {st }}$ ICN Buenos Aires 2017

\begin{tabular}{|c|c|c|c|c|}
\hline \multirow{2}{*}{$\begin{array}{l}\text { NOVA } \\
\text { Classification } \\
\text { system }\end{array}$} & \multirow[t]{2}{*}{ Type of products } & \multicolumn{3}{|c|}{$\begin{array}{l}\text { With nutrients } \\
\text { of concern }\end{array}$} \\
\hline & & $\mathrm{n}$ & $\mathrm{n}$ & $\%$ \\
\hline \multirow{19}{*}{$\begin{array}{l}\text { Group } 4 \text { - } \\
\text { Ultra- } \\
\text { processed }\end{array}$} & biscuits, crackers, cookies, wafers & 31 & 28 & 90,3 \\
\hline & cereals for breakfast & 18 & 15 & 83,3 \\
\hline & $\begin{array}{l}\text { premixes for desserts, cookies, atole, rice } \\
\text { pudding }\end{array}$ & 7 & 7 & 100,0 \\
\hline & cereal bar & 6 & 6 & 100,0 \\
\hline & yoghurt & 5 & 5 & 100,0 \\
\hline & dough for pies, empanadas, tart and tortillas & 4 & 4 & 100,0 \\
\hline & children's cereals & 4 & 4 & 100,0 \\
\hline & children's dairy products ${ }^{(*)}$ & 4 & 4 & 100,0 \\
\hline & ice cream and chocolate & 4 & 4 & 100,0 \\
\hline & milks with fruit juice & 3 & 3 & 100,0 \\
\hline & soups and broths & 3 & 3 & 100,0 \\
\hline & margarine & 3 & 3 & 100,0 \\
\hline & functional milks & 2 & 0 & 0,0 \\
\hline & seasonings & 2 & 2 & 100,0 \\
\hline & breaded soy or rice & 2 & 2 & 100,0 \\
\hline & flavoured waters & 2 & 2 & 100,0 \\
\hline & children's fruit-based food & 1 & 1 & 100,0 \\
\hline & spread cheese & 1 & 1 & 100,0 \\
\hline & fortified and sweetened tea & 1 & 1 & 100,0 \\
\hline \multirow{4}{*}{$\begin{array}{l}\text { Group } 1 \text { - } \\
\text { Minimally } \\
\text { processed }\end{array}$} & milks & 5 & \multirow{2}{*}{\multicolumn{2}{|c|}{$\begin{array}{l}\text { Not applicable } \\
\text { Not applicable }\end{array}$}} \\
\hline & bottled water & 2 & & \\
\hline & oats & 1 & \multicolumn{2}{|c|}{ Not applicable } \\
\hline & nuts & 1 & \multicolumn{2}{|c|}{ Not applicable } \\
\hline \multicolumn{2}{|l|}{ TOTAL } & 112 & & \\
\hline
\end{tabular}

${ }^{(*)} \mathrm{NB}$ : infant formulas were not advertised.

Table 4. Nutritional composition of ultra-processed products in the commercial area - IUNS $21^{\text {st }}$ ICN Buenos Aires 2017

\begin{tabular}{llrr}
\hline $\begin{array}{l}\text { Group according to NOVA } \\
\text { classification }\end{array}$ & Nutritional composition & $\mathrm{n}$ & $\%$ \\
\hline & added sugars in excess & 38 & 36.9 \\
\cline { 2 - 4 } & sodium in excess & 15 & 14.6 \\
\cline { 2 - 4 } & added sugars + sodium in excess & 14 & 13.6 \\
\cline { 2 - 4 } Group 4-Ultra-processed & added sugars + saturated fat in excess & 9 & 8.7 \\
\cline { 2 - 4 } & saturated fats + sodium in excess & 9 & 8.7 \\
\cline { 2 - 4 } & saturated fats in excess & 3 & 6.8 \\
\cline { 2 - 4 } & added sugars + saturated fats + sodium in excess & 2.9 \\
\cline { 2 - 4 } & no excess & 103 & 100.0 \\
\hline Total & &
\end{tabular}


Figure 5. Percentage distribution of exhibited products according to processing degree and amount of critical nutrients - IUNS 2017

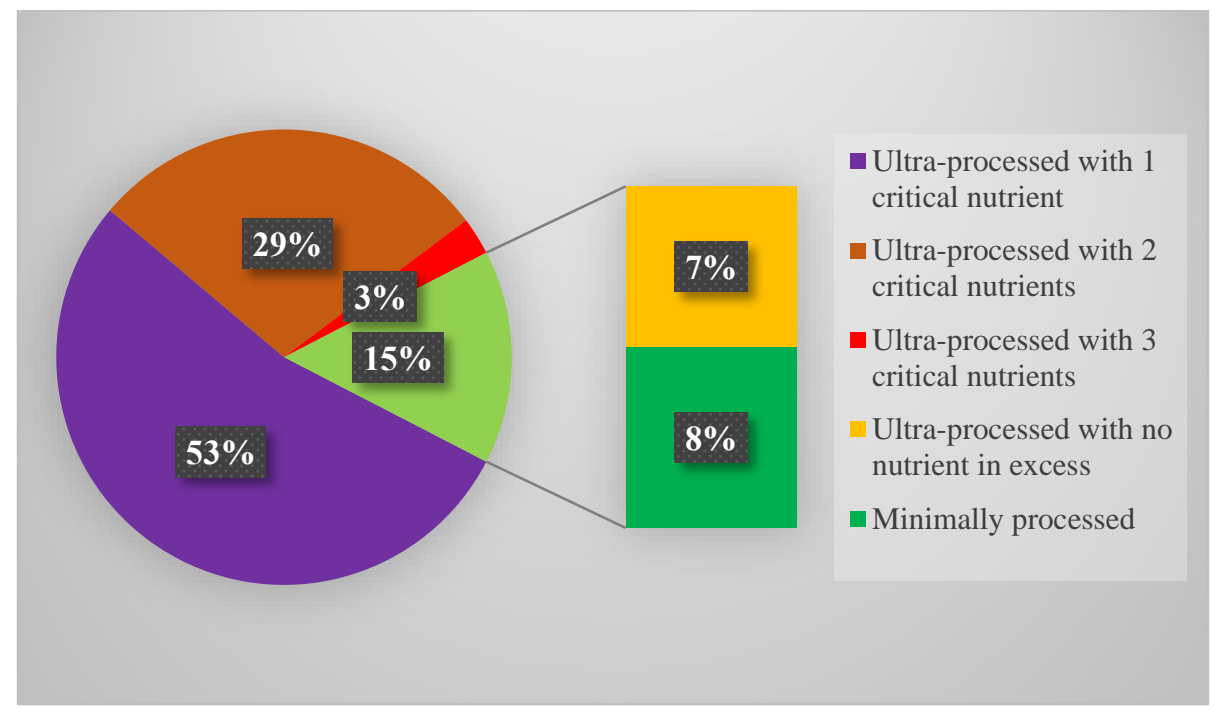

Sponsored symposia were organized on a schedule different from all other activities (from 5:00 pm to 7:00 pm), and they were specially identified in the Programme with the title "Sponsored Scientific Programme". 70\% of said sponsored symposia were organized by 8 of the 9 food companies, 4 of the 6 companies producing additives, and the 2 pharmaceutical ones, which had their own stands. The symposia were organized by research institutes or private foundations belonging to the commercial firms.

Furthermore, there were 7 sponsored symposia introduced by companies or associations of companies that had no presence within the commercial area. At the same time, two institutions associated to companies (Nestlé and Unilever) directly organized symposia in the non-sponsored programme. There were two professional entities that had commercial stands (Table 5).

The topics addressed at the sponsored symposia by the different companies (Table 5) were connected with the type of products exhibited, as well as with the core arguments presented at the stands and in flyers that they were healthy. By way of illustration, it should be noted that out of Nestlé's wide portfolio of brands and products, the stand exhibited bottled water, foods for young children (such us fruit puree, cereals), and breakfast cereals, highlighting the fortification of those foods with micro-nutrients. Three of the proposed symposia were focused on children's eating habits: dietary patterns, recommendations for parents, impact of the sugar intake.

PepsiCo selected Quaker from its product range, and proposed a symposium on whole grains and bioactive principles. Danone, a producer of baby foods, including infant formulas, bottled water, and dairy products that are marketed for specific populations (infants, young children, women), held symposia on toddler formulas, surveys about fluid intake, and the role of families in the development of children's eating habits.

The chairs and speakers that took part in the symposia organized by companies also participated in other activities included in the Scientific Programme (Table 6), namely $50 \%$ of the plenary conferences, which included the opening (Prentice, 2017a) and closing (Lartey, 2017) sessions, whose lecturers took part in symposia organized by institutions associated with Nestlé (Nestlé Nutrition Institute and Nestlé Foundation for the Study of Problems of Nutrition in the World) and with Unilever (Martins et al., 2017). Furthermore, among the special lectures, one was dedicated to the "Danone International Prize for Nutrition" of the prior year granted to a renowned researcher (Calder, 2017) that works as a consultant and receives payment for work done at Danone Nutricia Research. 
Table 5. Companies /associations organizing Sponsored and Parallel Scientific Symposia, with and without commercial stands - IUNS 21 ${ }^{\text {st }}$ ICN Buenos Aires 2017

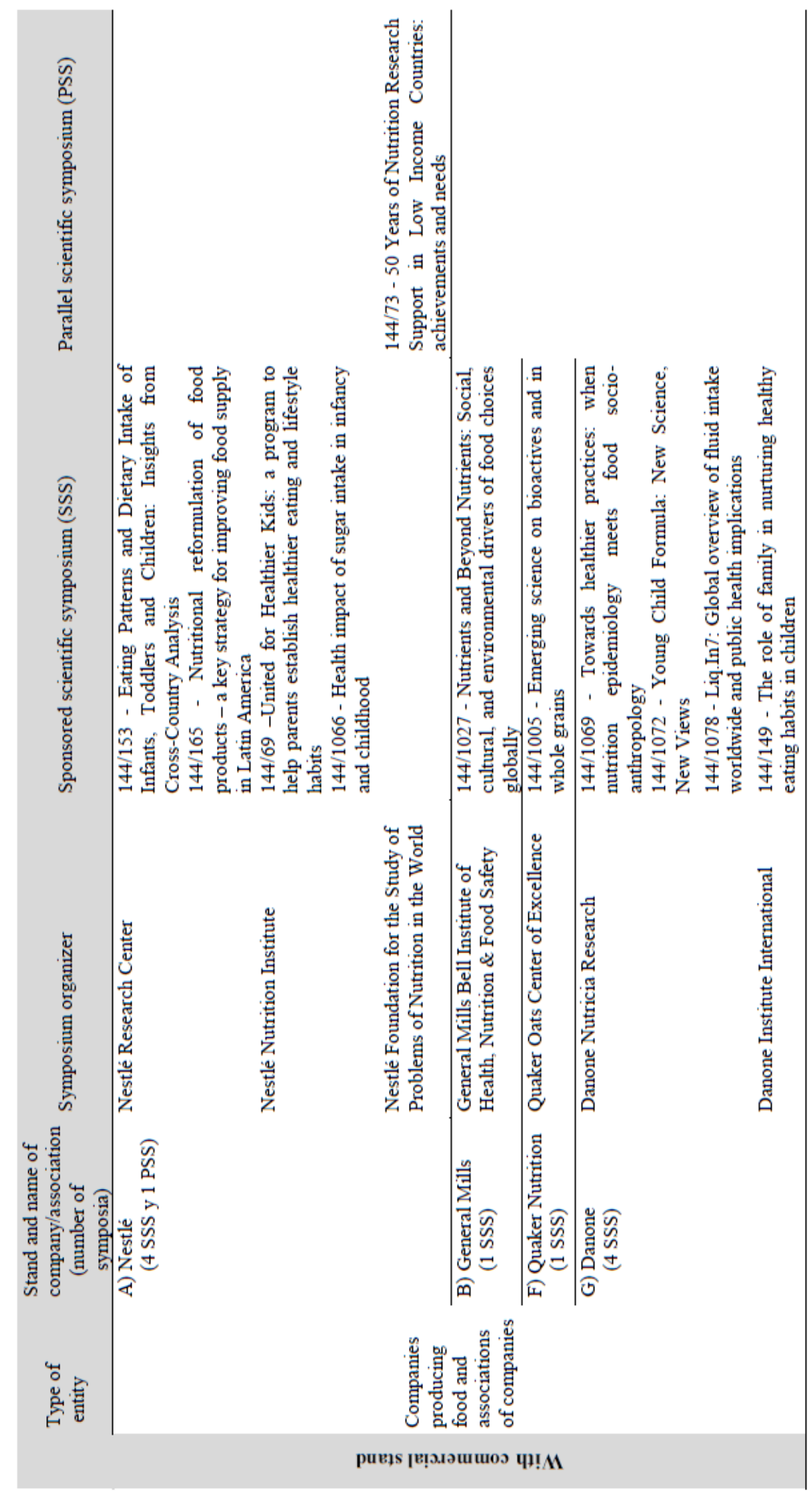




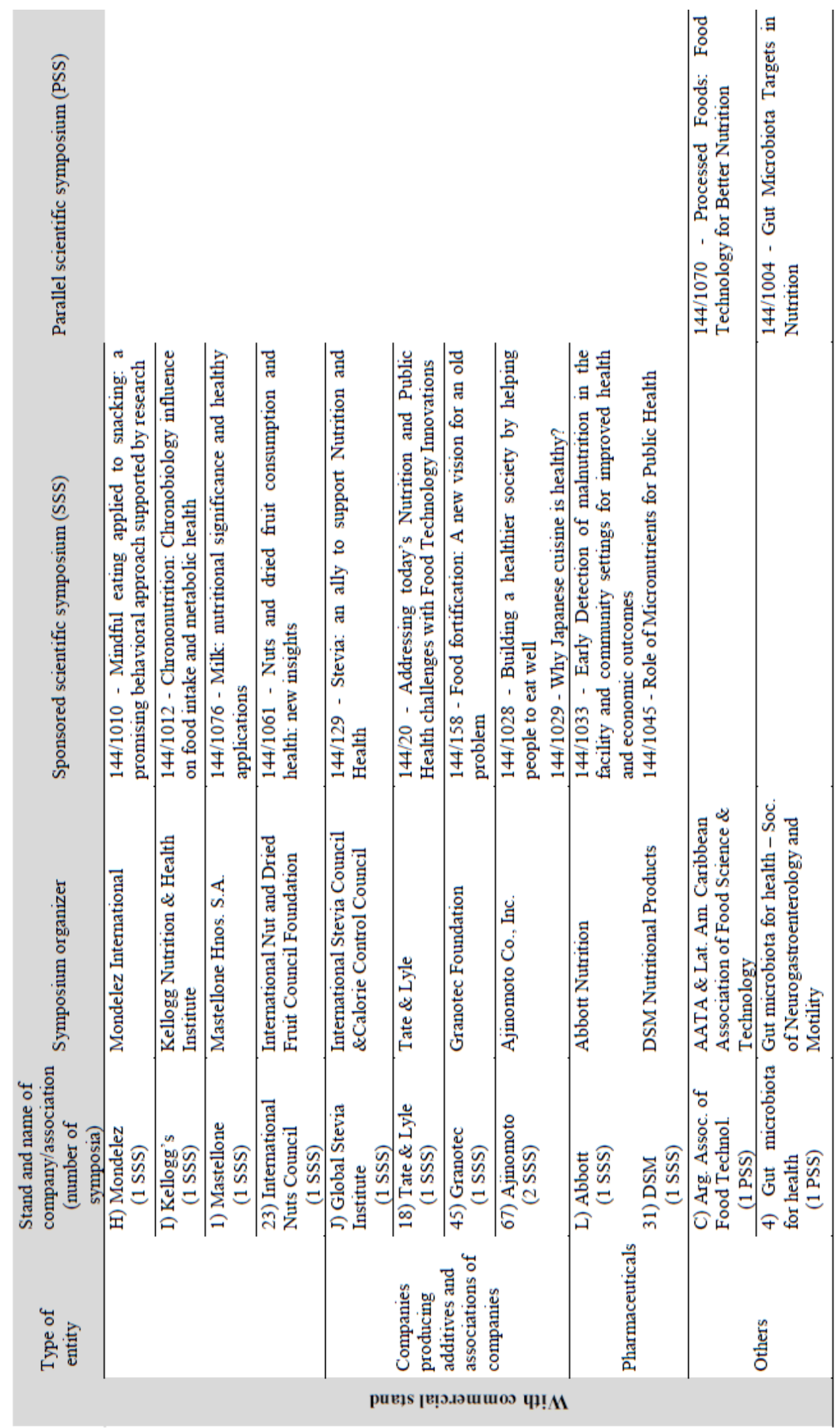




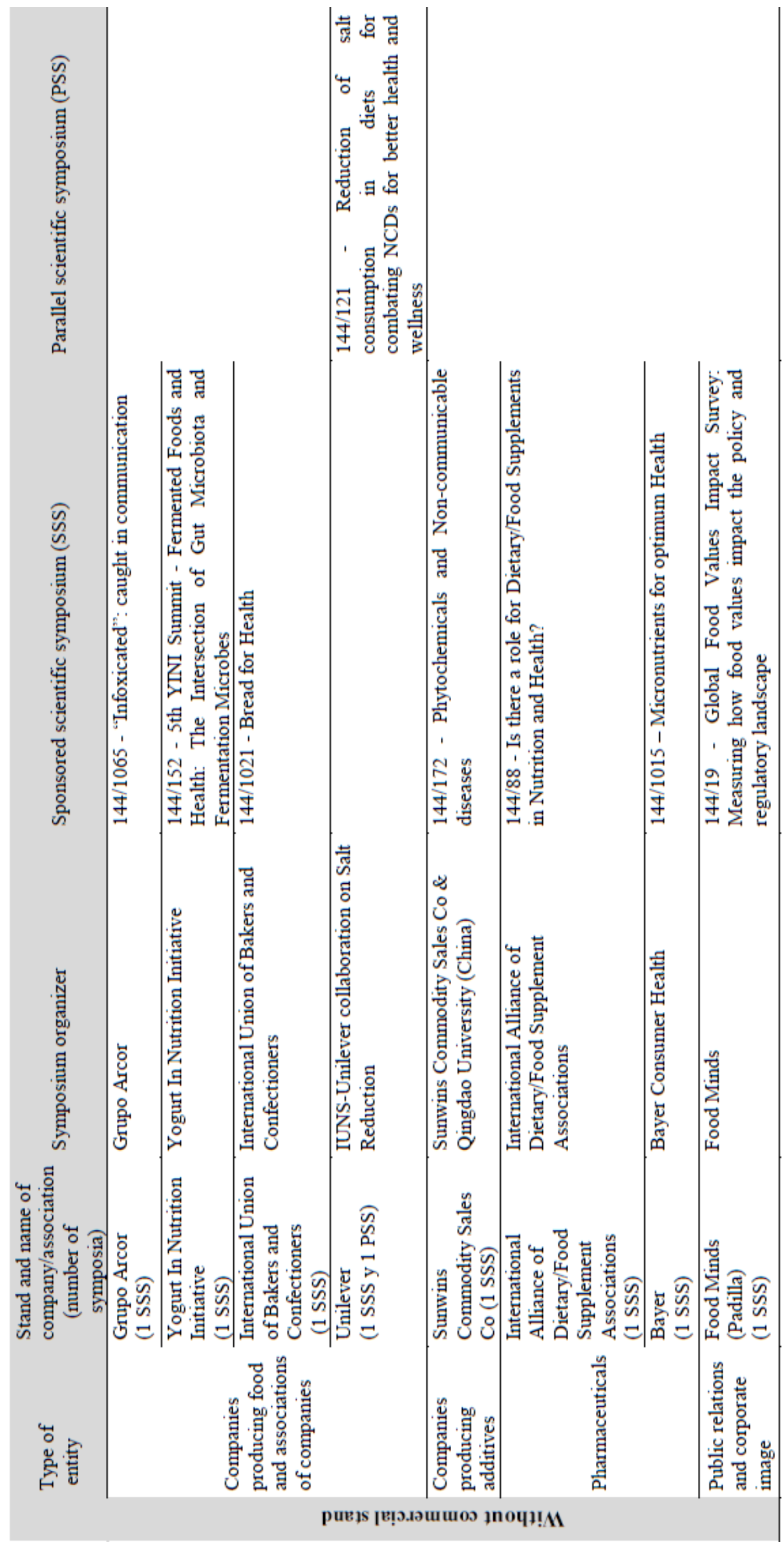


Table 6. Participation in the general program of lecturers in sponsored symposia - IUNS $21^{\text {st }}$ ICN Buenos Aires 2017

\begin{tabular}{|c|c|c|c|}
\hline \multirow{2}{*}{$\begin{array}{l}\text { General programme } \\
\text { activities } \\
\text { Type of activity }\end{array}$} & \multicolumn{3}{|c|}{$\begin{array}{r}\text { Activities with } \\
\text { participants of sponsored } \\
\text { programmes }\end{array}$} \\
\hline & $\mathrm{n}$ & $\mathrm{n}$ & $\%$ \\
\hline Satellite symposia & 24 & 7 & 29,2 \\
\hline Plenary conferences & 6 & 3 & 50,0 \\
\hline Special conferences & 40 & 10 & 25,0 \\
\hline Parallel symposia & 108 & 36 & 33,3 \\
\hline Total & 178 & 56 & 31,5 \\
\hline
\end{tabular}

Among the organizational entities of the 36 parallel symposia, (Table 7), one-third were organized by research centres or professional associations that received funding from large food and drink companies (Gomes, 2013), both sponsors and non-sponsors of the Congress.

It should be made clear that it was necessary to resort to sources of information external to the Congress publications, since the entities organizing the symposia were not required to declare conflicts of interest. For this reason, it was not possible to carry out a complete analysis of the participation of company funding in the parallel symposia.

The organizational committee of the Congress only required the declaration of conflicts of interest by speakers in panels, including the sponsored scientific symposia, or work presentations (either orally or through a poster). Such statements were limited to each specific presentation: "I have no conflict of interest to report in relation to this presentation" or "I wish to declare a potential conflict of interest, and that I have received either direct or indirect industry support from Company/-ies Name/s in relation to all or part of the results presented here”. No explicit statement was required regarding funding by companies of other professional activities of the lecturer (and the relevant membership institutions) within a larger time span (the last three years, for example).

Even at an individual level, the inclusion of a statement of conflicts of interest in the publication of abstracts was not uniform: all the conferences were omitted (both plenary sessions as well as special lectures), and it was irregular regarding symposia and work presentation, whether orally or through posters. Lecturers presented different statements depending on whether it was a sponsored symposium (Drewnowski, 2017a) (stating the corporate name) or not (Drewnowski, 2017b) (referring in a general way to granted prizes, contracts, and fees by private foundations and industries, among other sources).

The organizing institutions themselves (IUNS and SAN) did not make a public statement on the Congress official web site or on their institutional web sites regarding the financial support received by companies or other commercial entities.

Consequently, transparency in the statement of funding sources, usually accepted as a first fundamental (albeit not sufficient) step to deal with conflicts of interest (Nestle, 2018), was not complied with at an institutional level, and was limited to researchers.

The policy put forward by the IUNS and SAN to accept financial support and the presence of companies of foods and drinks was based on the segmentation of spaces and schedules by way of a supposed safeguard against conflicts of interest. Therefore, a wide hall was used to place the commercial stands and a special timetable was arranged that was different from the symposia explicitly organized by the companies. 
Table 7. Scientific institutions (with corporate funding) organizing parallel symposia where lecturers from sponsored symposia took part - IUNS 2017

\begin{tabular}{|c|c|c|}
\hline Organizer & $\begin{array}{l}\text { Funding from: } \\
\text { (according to cited sources) }\end{array}$ & $\begin{array}{l}\text { No. of } \\
\text { symposia }\end{array}$ \\
\hline $\begin{array}{l}\text { ILSI (International Life Sciences } \\
\text { Institute)(ILSI, 2016) }\end{array}$ & $\begin{array}{l}\text { Nestlé, General Mills, Pepsico, Danone, } \\
\text { Mondelez, Kellogg’s, Unilever, Abbott, } \\
\text { DSM, Ajinomoto, Herbalife, Tate\&Lyle, } \\
\text { Coca-Cola }\end{array}$ & 4 \\
\hline $\begin{array}{l}\text { CeSSIAM (Center for Studies of Sensory } \\
\text { Impairment, Aging and Metabolism) } \\
\text { (CeSSIAM, n.d.) }\end{array}$ & Nestlé Foundation & 1 \\
\hline $\begin{array}{l}\text { FINUT (Iberoamerican Nutrition } \\
\text { Foundation) (Rey-López \& Gonzalez, } \\
\text { 2019) }\end{array}$ & Coca-Cola & 1 \\
\hline $\begin{array}{l}\text { SEN (Spanish Nutrition Society)(Gomes, } \\
\text { 2015) }\end{array}$ & Coca-Cola & 2 \\
\hline $\begin{array}{l}\text { FEN (Spanish Nutrition Federation) } \\
\text { (Gomes, 2015) }\end{array}$ & Coca-Cola & 1 \\
\hline $\begin{array}{l}\text { Nestlé Foundation for the Study of } \\
\text { Problems of Nutrition(Nestlé Foundation, } \\
\text { n.d.) }\end{array}$ & Nestlé & 1 \\
\hline $\begin{array}{l}\text { SBAN (Brazilian Nutrition Society) } \\
\text { (SBAN, 2015) }\end{array}$ & Nestlé, Unilever, Coca-Cola & 1 \\
\hline $\begin{array}{l}\text { SAN (Argentine Nutrition Society) } \\
\text { (Piaggio, 2016) }\end{array}$ & Mastellone / La Serenísima & 1 \\
\hline Total & & 12 \\
\hline
\end{tabular}

However, sponsored activities organized by companies in the theoretically non-sponsored schedule (symposia, special lectures) were detected, and also the same lecturers from explicitly sponsored symposia were identified (evening schedule) in $30 \%$ of the other activities within the scientific programme. Similarly, it could be established that a third of all the organizational entities of those symposia received financial support from food companies.

Even in the theoretically non-sponsored schedule, the organizers provided an information spot and exchange contact for young researchers to approach members of Nestlé Foundation at specific times that were not in conflict with any other activity of the programme, to have a conversation on future or potential projects that could be assessed and funded by the foundation.

This was promoted through a flyer (Figure 6). In the same flyer, overleaf, on a white background, said, "You are cordially invited to meet with members from the Nestlé Foundation for the study of problems of nutrition in the world and discuss about potential research projects and capacity building activities which you plan in the future and which you might submit to the Nestlé Foundation for evaluation and funding”.

In the front of the flyer, behind the letters, as an image in the background, we can see a butterfly with blue wings on yellow flowers - with the wings in a V shape as if pollinating the flower - and to one side and creating a contrast effect, dry petals falling down. This is how a link is built between the butterfly pollinating the flower, associated with germination and production of life - in contrast with the dry petals falling down -, and Nestlé foundation as an institution that presents itself as an entity providing answers or solutions to nutritional problems-as indicated by the very title of the symposium being promoted, stressing the trajectory of research support in nutrition in low-income countries. 
Figure 6. Nestlé Foundation flyer - IUNS 21 ${ }^{\text {st }}$ ICN Buenos Aires 2017

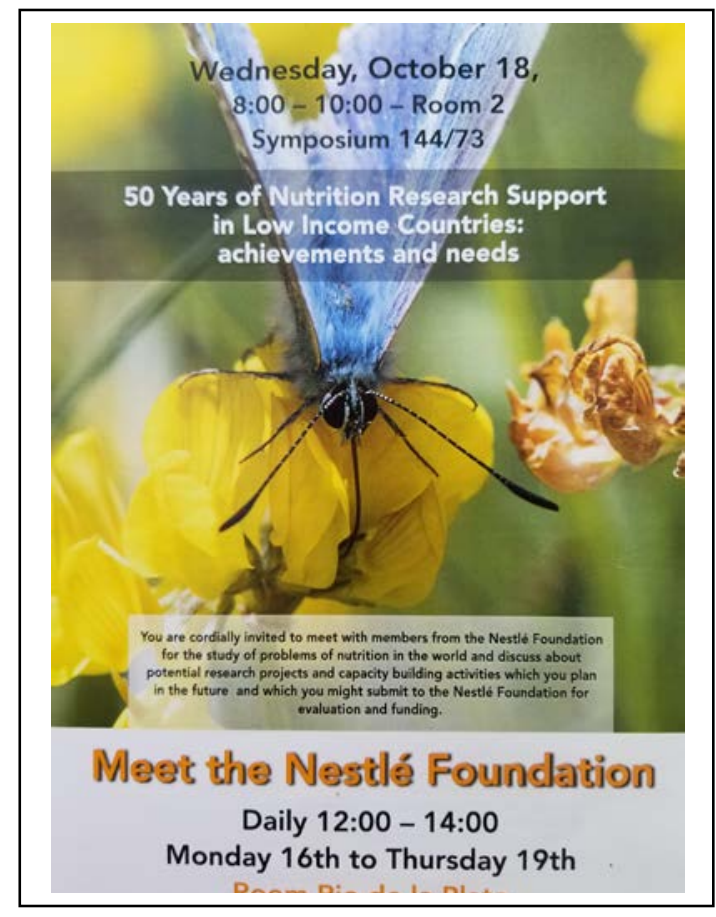

Photo: the authors

\section{Narratives that forge a health halo around ultra-processed products}

This section provides examples of narratives in corporate flyers and stands to advertise the products exhibited to professionals, aiming at providing a health halo (Whalen et al., 2018), and describes how these narratives are connected with presentations made during sponsored symposia and other activities of the Congress programme. A selection of products exhibited at the stands and named in the flyers and notices were presented by the companies as healthy options through narratives structured mainly about three core themes: fortification with micro-nutrients, reformulation of products (to decrease nutrients of concern), and symbolic reconversion of snacks (by creating a positive assessment and removing negative connotations). These narratives had parallels with the focus of the sponsored symposia and they were used to reinforce the health halo, as discussed below.

\section{Fortification with micro-nutrients}

Out of the 103 ultra-processed products mentioned in the flyers/notices or displayed at stands, $30 \%$ highlighted fortification with vitamins and minerals. Fortification was associated with "an optimal neurological and cognitive development” (Nestlé children's cereals), with "an aid to optimal physical growth and a healthy development" (Unilever premix for atole), and with "an answer to present-day nutritional needs of children....and pregnant women” (Danone dairy products).

For instance, at the stand of Nestlé under the motto "Nestlé for healthy kids" (Figure 7), a panel was included which read "Feed your baby like a baby" (presumably to disparage the introduction of family foods) while advertising trademarks like Cerelac, Nestum, Mucilon and Gerber, which stressed fortification with minerals (iron, zinc, iodine) and vitamins (A, C, B1). Flyers were handed out "exclusively to health professionals" containing information on the prevalence of anaemia in children under 2 years of age (in India) and abstracts of scientific works that assessed a risk reduction of anaemia for iron deficiency correlated to the consumption of "commercial fortified baby food" (PrietoPatron et al., 2017). These authors work at the Nestlé Nutrition Centre and the Nestlé Nutrition Institute India. In a flyer of Cerelac, a graphic was included comparing the contents of iron and its 
bioavailability in natural food (beef, lentils, spinach, broccoli), and in Nestlé children's cereals, affirming that commercial cereal was superior.

Figure 7. Nestlé commercial stand - IUNS $21^{\text {st }}$ ICN Buenos Aires 2017

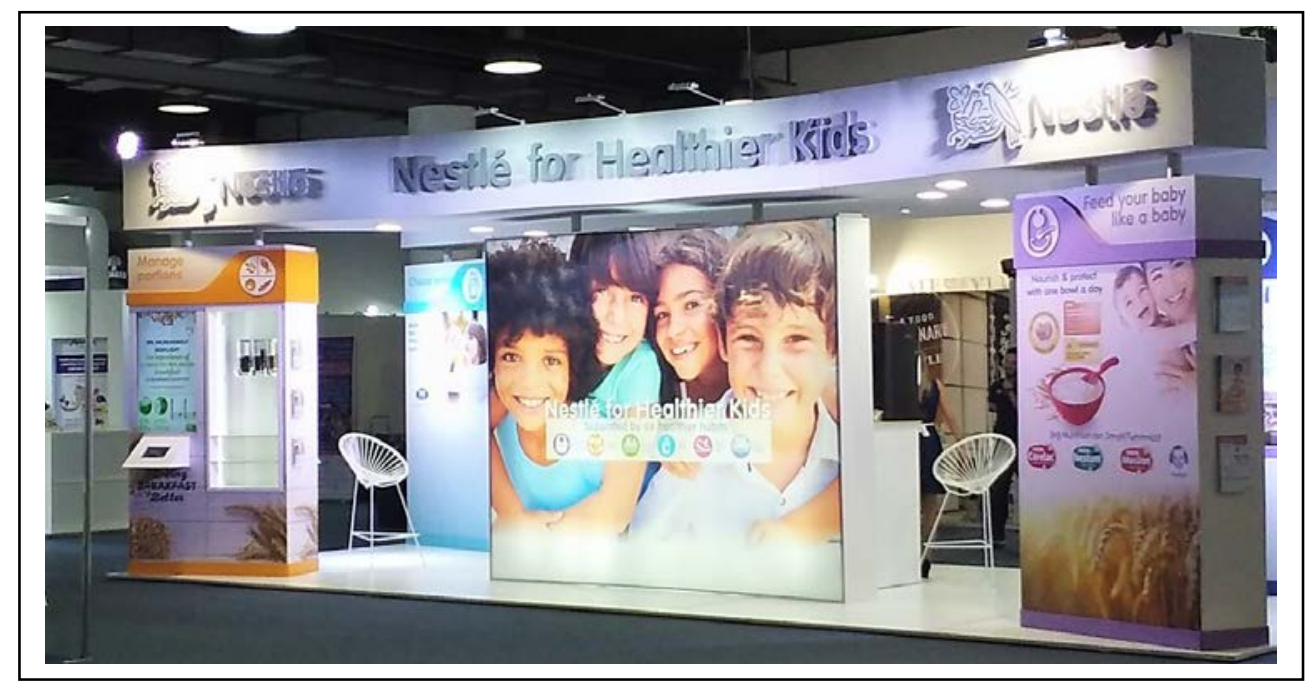

Photo: the authors

In one of the symposia sponsored by Nestlé named "Eating Patterns and Dietary Intake of Infants, Toddlers and Children: Insights from Cross-Country Analysis,” fortified children cereals are described as healthier options (Denney, 2017) but, strikingly, when the contributions of added sugars are analysed in children's eating patterns, they are not included (Eldridge, A., 2017).

In another symposium sponsored by Nestlé “A program to help parents establish healthier eating and lifestyle habits: Healthier Kids”, we learned that the slogan observed in the commercial stand "Feed your baby like a baby" is one of the six basic skills (Prentice, 2017b) around which the program intended to "educate" parents and/or guardians of infants and children under 12 years of age. The program was introduced as a strategy of social marketing that used massive media and social networking to reach parents and guardians directly.

It was launched in 2015 as a global initiative, but implemented only in medium and low-income countries. It utilized so-called private-public engagement, where leadership in defining contents and establishing alliances with other companies, governmental organizations and civil society was exercised by the private sector (Drewnowski, 2017a). All the lecturers and presentations in the symposium were compiled all and published in the ILSI-sponsored journal Nutrition Reviews. Each presenter/author was paid by the Scientific Advisory Board of the United for Healthy Kids (U4HK) program (Drewnowski et al., 2018).

\section{Reformulation of products}

Out of the 103 ultra-processed products, 14\% highlighted reformulation as a strategy to achieve a reduction in critical nutrient contents (added sugars, sodium, saturated, and trans fats) in their flyers.

They mentioned percentages: "25\% reduced added sugars" (children cereals), "up to 30\% reduced sugar" (breakfast cereals), and referred to the technological challenge to "maintain the level of sweetness" to retain palatability and acceptance of the products (Nestlé). "The Danonino range has improved in a lot of countries (...) reduction of sugar level by 9.6\%" (Danone). "100\% of the portfolio free of trans fatty acids” (Unilever).

The flyers briefly mention these reductions, stating some critical breaking points of nutrient contents and progressiveness in the accomplished goals, with some discrepancies by country/region, 
according to each company (Danone, Nestlé). They fail to mention any adverse health effect in the population caused by the nutrients of concern being reduced or the over-consumption of these critical nutrients. This is totally contrary to the previous point because when showing the fortification of their products, descriptions abound of the organic function of the different micro-nutrients and the harm caused by inadequate consumption at a population level, even by making references to published literature.

During the symposium "Nutritional reformulation of food products - a key strategy for improving food supply in Latin America” (organized by: Nestlé Research Center), a nutrient profile system developed by Nestlé was presented and self-regulation and the development of agreements within the industry was proposed, in a multi-stake holder partnership context (Masset, 2017).

More precisely, this Nestlé's symposium was focused on an area where greater advances have been made in the implementation of statutory regulations leading to a mandatory establishment of front labelling warning systems (FAO et al., 2018), and to the elimination or reduction of two nutrients of concern (trans fats, sodium) in some countries, measures recommended by PAHO-WHO. As advancements were seen (though there are many obstacles) regarding regulatory measures, the industry is responding via self-regulatory practices (Moodie et al., 2013).

In addition, we found that the coordinator of the Symposium on reformulation put forward in a parallel symposium called "Perspectives on nutrient density: too high and too low" the following: "In the face of the shrinking energy as the denominator factor, public health tolerance for 'empty calories' is reduced, while an imperative to construct dietary fares from micronutrient-enhanced calories will become evident” (Solomons, 2017) making it clear that both narratives (fortification and reformulation) are intertwined to install ultra-processed products as being healthy.

Clapp and Scrinis (2017) argue that both fortification and reformulation of food products are strategies that exclusively place their focus on individual nutrients. These are examples of what the Australian researcher (Scrinis, 2008) has called nutritionism: reduction of the nutritional value of food to individual nutrients and the simplified and exaggerated estimation of their role in human health, while neglecting other factors important for health that are obtained mainly from natural foods.

\section{Symbolic reconversion of snacks}

Only $30 \%$ of the ultra-processed products were labelled as snacks in the flyers. An important semiotic work was developed in the flyers to re-signify them, eliminating negative connotations. In that way positive adjectives are used to describe the act of eating snacks, calling it: "healthy snacking" (Danone), "smart snacking” (General Mills) and “mindful snacking” (Mondelez).

In the first case (healthy) it was exemplified with an advertising campaign designed to position a yoghurt brand as a healthy snack in Argentina in the year 2015. In the second case (smart), the recommendation of "using snacks as resources to upgrade diet, "was recommended in the flyers, suggesting the consumption of a food from a group lacking in the diet or consumed in less than recommended quantities; or diets with a deficient nutrient, using their own brands of cereal bars and yoghurt as examples. In the third case (mindful), the emphasis was not placed on the nutritional composition of the product but on the serving size, and self-regulation of the intake magnitude in the flyer's references to sweet crackers, savoury crackers and chocolate, which were types of products displayed at the commercial stand.

The advertising campaign developed in Argentina in the year 2015 by Danone called "The healthy snack month" (September) was preceded by two market surveys. In one of them they collected snacking patterns which provided evidence of the categories of foods usually consumed. In another one they modelled substitution alternatives among the categories, in order to position the new yoghurt as one "reliable and healthy alternative" (Danone, 2016). The first survey was published by the renowned Centre of Nutrition Research (CESNI) as an executive abstract for a research project (Zapata et al., 2015), with no reference to the funding sources, some months earlier (May). This received a 
broad coverage in mass and digital media, instilling in the discourse of mass media the term snacking, associating this word to the possibility of healthy choices. Hence, the advertising campaign presented the yoghurt as the best solution to the problem posed: a healthy product for snacking habits. The company highlighted in its flyers that this campaign had been based on the "Healthier choice study" focused on understanding consumer behaviour. However, during the presentation of the study in one of the symposia sponsored by Danone, the director of CESNI (Carmuega, 2017) declared a lack of conflicts of interest and omitted mentioning the overlap between the study presented and the design of products and advertising campaigns.

The symposium sponsored by Mondelez intended to develop the application of the "mindful eating" approach to snacking. The lecturers suggested the need to transform an impulsive, irregular, externally activated behaviour into a fairly regular and conscious eating event (Bellisle, 2017), trying to achieve the maximum pleasure from small quantities, without restricting the type of products (Kristeller, 2017).

Mindful snacking was proposed as an alternative to health warnings, which would help encourage consumers to take in snacks more healthily (Cornil, 2017). These efforts to re-signify snacking by creating a positive assessment of it are linked to the narrative that presents healthy eating as the result of individual choices and thus as the sole responsibility of consumers.

\section{DISCUSSION}

As stated above, the 21st International Congress of Nutrition was sponsored by major corporations producing foods and drinks known as "Big Food". During the event, ultra-processed products were advertised to health professionals, out of which $85 \%$ were high in added sugars, sodium, and/or saturated fats.

Various studies have established direct and significant dose-response associations between the proportion of ultra-processed products in the diet and the excessive intake of added sugars, saturated fats, trans fats, and sodium (Monteiro et al., 2018). There is a significant body of scientific evidence that relates ultra-processed products with the risk of suffering from obesity, cardiovascular and metabolic diseases (Monteiro et al., 2019).

Several authors maintain that large corporations resort to nutritional references to strengthen their power and influence within the food sector (Clapp \& Scrinis, 2017; Nestle, 2018). One of the ways to position themselves is precisely through participation in congresses and forums addressing nutritional topics. This has multiple and complex implications, from getting a better positioning of their products on behalf of the scientific community, health professionals and the population in general, to influencing regulations, all with the aim of assuring their viability and profitability over time (Clapp \& Scrinis, 2017).

In this sense, it proves to be paradoxical that the International Nutrition Congresses host international corporations and their ultra-processed products, contributing to industry strategies which involve questioning the evidence that links them with the main causes of morbidity and mortality rates (Monteiro et al., 2018; Monteiro, 2017) while seeking to endow ultra-processed products with a "health halo" (Whalen et al., 2018).

The policy put forward by the organizing entities (IUNS and SAN) as a safeguard against conflicts of interest introduced by the industry funding and presence was based on a space-time segmentation of the activities and on the requirement to submit a statement declaring conflicts of interest through a standardized declaration limited to each lecturer's presentation.

The borders between commercial and scientific spaces proved to be intentionally porous: all attendees had to go across the commercial area to complete their registration process, and failure by the Congress organizers to provide foods and beverages for the intervals encouraged the attendees to go to that area to consume products that were given for free, along with flyers and "brand reminders" as gifts. 
The separation of schedules different from the sponsored symposia also proved to be ineffective. They were considered an integral part of the Scientific Programme and their lecturers also took part in $30 \%$ of the other activities included in the programme. Some of these were even organized by scientific or professional entities funded by food corporations, but this aspect could not be deeply analysed because institutional statements of conflicts of interests were not required.

These measures adopted to deal with the conflicts of interest suggest pursuit of a policy of institutionalized opacity: showing one part in order to hide the complete picture and to blur the ramifications of industrial sponsorship in scientific discussions and debates during the Congress. Although the Congress included a wide variety of institutions and approaches, this situation typifies the infiltration of commercial interests into scientific discussions (Monteiro, 2017) and the resulting risk of industry bias in public policies and dietary recommendations.

This influence was clear in the narratives in the flyers about the products exhibited at the commercial stands and the relationship with the themes and presentations in sponsored symposia and other scientific activities. Three thematic axes were identified to provide a health halo: fortification with micro-nutrients, reformulation of products, and symbolic reconversion of snacks.

These narratives exemplify a "below the line" advertising strategy (Moodie et al., 2013) camouflaged as education programmes that highlight the food industry narrative of individual responsibility and freedom of choice (Brownell \& Warner, 2009; Clapp \& Scrinis, 2017). In addition, the companies present themselves as stakeholders and leaders when it comes to developing public health nutrition interventions. Consequently, the corporate image is improved, and a protective shield is constructed against criticisms of the degree of processing and unsuitable nutritional profile of ultraprocessed foods.

It should be noted that due to the global increase in non-communicable chronic illnesses-which is even higher during paediatric ages-governments are discussing and regulating-or looking for a way of regulating-the advertising and labelling of food, school environments and taxation on sugared drinks (UNICEF, 2018). Corporate appropriation and manipulation of nutritional scientific knowledge allows them to adapt to the changing public health nutrition climate, to maintain influence, to delay/avoid regulations, and to create a space that maintains profitability for their business (Clapp \& Scrinis, 2017).

Even some authoritative voices echo these narratives favouring the "Big Food", for instance in the Congress' opening session: "Many in our field treat the food industry with a level of antagonism that blocks constructive dialogue. If global multinationals are part of the problem they must surely be part of the solution" (Prentice, 2017a)

\section{What this study adds and implications}

This study aimed to raise attention to the problem of corporate sponsorship in scientific events, in particular in the nutrition field. There is a contradiction in giving companies a place in a healthrelated event whose products and practices of production and commercialization are closely connected with the major causes of morbidity and mortality worldwide (obesity, cardiovascular and metabolic chronic diseases)(Gomes, 2015).

By the 1970s, it became evident, in the case of breast milk substitutes, that health professionals sometimes acted as marketing targets and even agents of food companies (for example, distributing free samples). Companies seek to fund professional associations and scientific events as part of their advertising and corporate image management strategies (Bodini et al., 2009; Canella et al., 2015). One goal is to separate themselves from the genesis of malnutrition. This can introduce real or perceived bias, which may distort health recommendations and messages (Gomes, 2015).

This study in particular has gathered documentary evidence to show that in the case of the 21st International Nutrition Congress, the products advertised to health professionals were ultra-processed with nutrients of concern in excess. The Congress offered an opportunity of providing these products 
with a health halo. It was clear that the measures implemented by the organizing entities to try and avoid the risks introduced by corporate sponsorship were ineffective.

\section{Strengths and limitations of this study}

The strength of this study was the exhaustive data collection and documentation of the products advertised in the commercial exhibition area, the analysis of their nutritional profile and the narratives developed to provide them with a health halo. One limitation was ignoring sponsorship by pharmaceutical, additives, and diet supplement companies. In addition, it was impossible to thoroughly reveal conflicts of interest regarding the whole Congress programme due to the lack of requirement of institutional statements.

\section{Further research and recommendations}

Further research is needed to document and compare different strategies that professional associations are developing to deal with conflicts of interest, as is the case for instance of the Latin American Society of Nutrition (Barquera et al., 2018).

Observational approaches and documentaries would be enriched if they were complemented with interviews with organizers, lecturers and attendees, so as to be able to integrate the perspective of actors participating in these scientific events.

Similarly, it would be relevant to link inquiry on the narratives built around ultra-processed products with an important field of theoretical-conceptual reflection: biomedicalization (Clarke et al., 2003) of daily life, delving into the implications of nutritionism (Scrinis, 2008) and attribution of individual responsibility.

\section{CONCLUSIONS}

Having documented the influence of corporate sponsorship from food companies in the narratives about their products in a scientific congress helps us to challenge the efficacy of the measures adopted by the organizers to deal with conflicts of interest. In the case of the 21st International Nutrition Congress, these measures could more closely be characterized as a policy of institutionalized opacity.

It is paradoxical that in a space designed for updating and exchanging evidence among health professionals, companies are allowed to advertise their products and practices that are harmful for public health.

It is vital to guarantee the transparency of funding sources for professional and scientific entities as an immediate measure and to advance the development of stricter standards to prevent sponsorship from companies that commercialize unhealthy products. 


\section{REFERENCES}

ANMAT. (2014). Argentina, pionera en la regulación de grasas trans en alimentos. http://www.anmat.gov.ar/comunicados/Articulo_Grasas_Trans.pdf

Barquera, S., García Chávez, G., Sánchez, K., Boukerdenna, H., Uauy, R., Pérez Escamilla, R., Martorell, R., Ramírez Zea, M., \& Navarro Rosenblatt, D. (2018). Postura sobre el manejo de conflicto de intereses Consejo Directivo de la SLAN 2015-2018. https://www.slaninternacional.org/conflictointeres/docs/170801_Postura_CDI_SLAN_2017.pdf

Bellisle, F. (2017). Snacking in different parts of the world: a marker of dietary anarchy or a useful contributor to diet quality and weight control. Ann NutrMetab, 71(suppl 2), 1339.

Bodini, C., Martino, A., \& McCoy, D. et al. (2009). How to stop public health conferences becoming trade fairs. Public Health Nutrition, 12(9), 1581-1583. https://doi.org/10.1017/S1368980009990863

Brownell, K. D., \& Warner, K. E. (2009). The perils of ignoring history: Big tobacco played dirty and millions died. How similar is big food? Milbank Quarterly, 87(1), 259-294. https://doi.org/10.1111/j.1468-0009.2009.00555.x

Calder, P. (2017). Feeding the immune system: the Danone International Prize for Nutrition 2016. Ann NutrMetab, 71(suppl 2), 22.

Canella, D. S., Paula, A., \& Martins, B. et al. (2015). Food and beverage industries' participation in health scientific events: considerations on conflicts of interest. Rev Panam Salud Publica, 38(4), 339-343.

Carmuega, E. (2017). Analyse populations' diet and dynamics between food categories to support healthier choices. Concrete examples from 2 Argentinian studies. In Abstract book 21st INC Danone Nutricia Research Sponsored Symposium.

Carrera, M., Gil, A., \& Martinez, J. A. (2017). IUNS. 21st International Congress of Nutrition. Buenos Aires, Argentina, October 15-20, 2017: Abstracts. Annals of Nutrition \& Metabolism, 71(suppl 2), 1-1433. https://doi.org/10.1159/000480486

CeSSIAM. (n.d.). CeSSIAM - our sponsors. Retrieved January 14, 2020, from https://www.hgrunowfoundation.org/en/cessiam/

Charmaz Katie. (2006). Constructing grounded theory. A practical guide through qualitative analysis. Sage.

Clapp, J., \& Scrinis, G. (2017). Big Food, Nutritionism, and Corporate Power. Globalizations, 14(4), 578-595. https://doi.org/10.1080/14747731.2016.1239806

Clarke, A. E., Mamo, L., \& Fishman, J. R. . et al. (2003). Biomedicalization: Technoscientific transformations of health, illness, and U.S. biomedicine. American Sociological Review, 68(2), 161-194. https://doi.org/10.2307/1519765

Cornil, Y. (2017). How mindfulness can benefit to snacking? Ann NutrMetab, 71(suppl 2), 1340.

Danone. (2016). Nutrition health achievements 2016. https://tinyurl.com/saukwg6

Denney, L. et al. (2017). Complementary feeding and the transition to foods of the family table in China, Mexico, Russia and US. Ann NutrMetab, 71(suppl 2), 1335.

Drewnowski, A. (2017). From PPP to PPE: a new opportunity for engagement. Ann NutrMetab, 71(suppl 2), 1343.

Drewnowski, A. (2017). Nutrient-energy density: origins of the concept. Ann NutrMetab, 71(suppl 2), 259.

Drewnowski, Adam, Caballero, B., Das, J. K., French, J., Prentice, A. M., Fries, L. R., Van Koperen, T. M., Klassen-Wigger, P., \& Rolls, B. J. (2018). Novel public-private partnerships to address the double burden of malnutrition. Nutrition Reviews, 76(11), 805-821. 
https://doi.org/10.1093/nutrit/nuy035

Eldridge, A. et al. (2017). Intake of total and added sugars among children in Australia, China, Mexico, Russia and US. Ann NutrMetab, 71(suppl 2), 1335.

FAO, OMS, OPS, \& PUC. (2018). Políticas y programas alimentarios para prevenir el sobrepeso y la obesidad. https://tinyurl.com/ur8lpzd

Freedhoff, Y., \& Hébert, P. C. (2011). Partnerships between health organizations and the food industry risk derailing public health nutrition. Cmaj, 183(3), 291-292. https://doi.org/10.1503/cmaj.110085

Gomes, F. da S. (2013). Big Food Watch. Words for Our Sponsors. Commentary. World Nutrition, 4(8), 618-644. https://worldnutritionjournal.org/index.php/wn/article/view/297/246

Gomes, F. da S. (2015). Conflicts of interest in food and nutrition. Cadernos de Saude Publica, 31(10), 1-8. https://doi.org/10.1590/0102-311XPE011015

Guber, R. (2001). La observación participante. In La etnografía. Método, campo y reflexividad. Norma.

Harris, J. (2019). Narratives of nutrition : Alternative explanations for international nutrition practice. World Nutrition, 10, 99-125. https://worldnutritionjournal.org/index.php/wn/article/view/672/589

Hoffman, B. (2013). Behind the Brands: Food justice and the 'Big 10' food and beverage companies. https://www.oxfam.org/en/research/behind-brands

ILSI. (2016). Member and Supporting Companies. http://ilsi.org/wpcontent/uploads/2016/01/Members.pdf

Institute of Medicine. (2009). Conflict of Interest in Medical Research, Education, and Practice. The National Academies Press. https://doi.org/10.17226/12598

International Union of Nutritional Sciences. (n.d.). 21st IUNS-ICN 2017, Buenos Aires, Argentina. https://iuns.org/21st-iuns-icn-2017-buenos-aires-argentina/

Ioannidis, J. P. A. (2012). Are medical conferences useful? And for whom? JAMA - Journal of the American Medical Association, 307(12), 1257-1258. https://doi.org/10.1001/jama.2012.360

Kristeller, J. (2017). Eating mindfully as a sustainable healthy behavior: theory and evidence. Ann NutrMetab, 71(suppl 2), 1339-1340.

Lartey, A. (2017). Our quest for healthy diets: the role of nutrition scientists. Ann NutrMetab, 71(suppl 2), 9.

Martins, F., Leroy, J., Verstraeten, Roos;, \& Lartey, A. (2017). Global nutrition leadership: perspectives from the corporate sector. Ann NutrMetab, 71(suppl 2), 194.

Masset, G. et al. (2017). Nutrient profiling for product reformulation: the benefit for the consumer. Ann NutrMetab 71(2), 1364.

Monteiro, Carlos A., Cannon, G., \& Levy, R. B. . et al. (2019). Ultra-processed foods: What they are and how to identify them. Public Health Nutrition, 22(5), 936-941. https://doi.org/10.1017/S1368980018003762

Monteiro, Carlos A., Cannon, G., \& Moubarac, J. C. et al. (2018). Ultra-processing. An odd “appraisal.” Public Health Nutrition, 21(3), 497-501.

https://doi.org/10.1017/S1368980017003287

Monteiro, Carlos Augusto. (2017). Infiltración conflictiva. Brecha. https://brecha.com.uy/infiltracion-conflictiva/

Monteiro, Carlos Augusto, Cannon, G., \& Lawrence, M. et al. (2019). Ultra-processed foods, diet quality, and health using the NOVA classification system. FAO.

Monteiro, Carlos Augusto, Cannon, G., \& Moubarac, J. C. et al. (2018). The un Decade of Nutrition, the NOVA food classification and the trouble with ultra-processing. Public Health Nutrition, 
21(1), 5-17. https://doi.org/10.1017/S1368980017000234

Moodie, R., Stuckler, D., \& Monteiro, C. et al. (2013). Profits and pandemics: Prevention of harmful effects of tobacco, alcohol, and ultra-processed food and drink industries. The Lancet, 381(9867), 670-679. https://doi.org/10.1016/S0140-6736(12)62089-3

Nestlé Foundation. (n.d.). The Nestlé Foundation for the Study of Problems of Nutrition in the World. Retrieved January 14, 2020, from http://www.nestlefoundation.org/e/about.html

Nestle, M. (2018). Unsavory truth: how food companies skew the science of what we eat. Basic Books.

PAHO. (2016). Pan American Health Organization Nutrient Profile Model. http://iris.paho.org/xmlui/bitstream/handle/123456789/18621/9789275118733_eng.pdf

Peña Vera \& Pirela Morillo, J. (2007). La complejidad del análisis documental. Información, Cultura y Sociedad, 16, 55-81. https://doi.org/10.34096/ics.i16.869

Piaggio, L. R. (2016). The right to food in obesogenic environments: Reflections on the role of health professionals. Salud Colectiva, 12(4), 605-619. https://doi.org/10.18294/sc.2016.934

Prentice, A. (2017a). Fit for the future: aligning nutritional sciences for the service of humanity. Ann NutrMetab, 71(suppl 2), 7.

Prentice, A. (2017b). United for healthier kids: a program to help parents establish healthier eating and lifestyle habits. Ann NutrMetab, 71(suppl 2), 1343.

Prieto-Patron, A., Hutton, Z. V, \& Garg, P. et al. (2017). The Association between Complementary Foods and Hemoglobin Concentrations in Indian Infants. Journal of Human Nutrition \& Food Science, 5, 1-11.

Rey-López, J. P., \& Gonzalez, C. A. (2019). Research partnerships between Coca-Cola and health organizations in Spain. European Journal of Public Health, 29(5), 810-815. https://doi.org/10.1093/eurpub/cky175

Richter, J. (2005). Conflicts of Interest and Policy Implementation Reflections from the fields of health and infant feeding. In IBFAN-GIFA. http://info.babymilkaction.org/sites/info.babymilkaction.org/files/COlbooklet.pdf

SBAN. (2015). Sociedade Brasileira de Alimentação e Nutrição 30 anos. https://tinyurl.com/sban30

Scrinis, G. (2008). On the Ideology of Nutritionism. Gastronomica, 8(1), 39-48. https://doi.org/10.1525/gfc.2008.8.1.39

Solomons, N. (2017). Application of the concept in a public health context. Ann NutrMetab, 71(suppl 2), 254.

Stuckler, D., \& Nestle, M. (2012). Big food, food systems, and global health. PLoS Medicine, 9(6), 7. https://doi.org/10.1371/journal.pmed.1001242

Underwood, B. (2007). IUNS - International Union of Nutritional Sciences. Food \& Nutrition Research, 51(1). https://doi.org/10.3402/fnr.v51i1.1609

UNICEF. (2018). Obesidad: una cuestión de derechos de niños, niñas y adolescentes. https://tinyurl.com/v6z4n5n

Whalen, R., Harrold, J., \& Child, S. et al. (2018). The health halo trend in UK television food advertising viewed by children: The rise of implicit and explicit health messaging in the promotion of unhealthy foods. International Journal of Environmental Research and Public Health, 15(3), 560. https://doi.org/10.3390/ijerph15030560

WHO. (n.d.). DECLARATION OF INTERESTS (WHO EXPERTS ). https://www.who.int/about/ethics/doi-guide-EN.pdf?ua=1

Zapata, M. E., Rovirosa, A., \& Carmuega, E. (2015). Patrones de snackeo de la población Argentina “Resumen ejecutivo.” In Cesni. https://cesni.org.ar/patrones-de-snackeo-de-la-poblacionargentina/ 